Proceedings

\title{
A New Massive (omics) Analysis for Fruit Development and Other Important Traits in Prickly Pear (Opuntia spp) ${ }^{\dagger}$
}

\author{
Luis Alfredo Cruz-Ramirez ${ }^{1}$, Mario Arteaga-Vazquez ${ }^{2}$ and Andres Cruz-Hernandez ${ }^{3, *}$ \\ 1 LANGEBIO-CINVESTAV IPN, Unidad Irapuato, km 9.6 Irapuato-León, Irapuato, Gto. Mexico; \\ alfredo.cruz@cinvestav.mx \\ 2 Institute for Biotechnology and Applied Ecology, Universidad Veracruzana (INBIOTECA-UV), Veracruz, \\ Mexico; marioarteagavazquez@gmail.com \\ 3 Escuela de Agronomía Universidad De La Salle Campus Campestre, Av. Universidad 602, León, Gto. \\ Mexico \\ * Correspondence: andrex1998@hotmail.com; Tel.: +52-477-73500 \\ + Presented at the 1st International Electronic Conference on Plant Science, 1-15 December 2020; Available \\ online: https://iecps2020.sciforum.net/.
}

Published: 30 November 2020

\begin{abstract}
Prickly pear (cactus fruit) is an important crop in Mexico, it helps to the establishment of Mexican antique civilization. As a ripening model, it has a unique character because include morphospecies with contrasting characteristics, making easier their interpretation. The main commercialization problems for prickly pear include the presence of seeds and spines (gloquids), it would be interesting to idenfied the genetic factors involve in their synthesis of these structures, through genetic expression in order to design some strategy for their control. In this study we have been used different molecular and bioinformatics strategies for the identification of the factors related to prickly pear development. In proteomics assays using three morphospecies with contrasting development and fruit ripening, it was possible to identified the minimal number of required peptides for fruit development and ripening delay, also were identified peptides associated to regulatory functions in transcendental metabolic functions. In the miRNA transcriptome, were identified 255 molecules associated to the fruit development and other important process, such as adaptation to extremal growth conditions, were cactus plants growth. Seven families of miRNAs were associated to fruit development and plant adaptation, and the pathway of miRNA participation was determined. The expression assays shown the effects of miRNAs on fruit development in prickly pear.
\end{abstract}

Keywords: cactus fruit; differential expression; gene expression; miRNAs; proteomics

\section{Introduction}

The semi-arid region of Mexico hosts the greatest genetic diversity of prickly pear in the world. Prickly pear can adapt to a variety of climatic conditions and has a great diversity of uses. Prickly pear fruits are classified as non-climacteric fruits on the basis of respiration rates. On the basis of fruit development, there are prickly pears of early, intermediate, and late ripening [1], depending on the time required for full fruit development from anthesis to physiological maturity, make it a model to study fruit development.

Fruit development is a highly complex, strictly coordinated, genetically programmed, irreversible phenomenon involving a series of physiological, biochemical, and organoleptic changes that lead to the development of a soft and edible ripe fruit with desirable quality attributes [2]. The ability to understand key control points in the global ripening regulation or within specific ripening processes, such as carotenoid, flavonoid, vitamin, and flavor volatiles synthesis, will allow the manipulation of nutrition and quality characteristics associated with ripening [3].

It is now hypothesized that biological processes and systems can be described based on the comparison of global and quantitative gene expression patterns from cells or tissues representing 
different stages. The protein level integrates posttranscriptional and post-translational processing that modulates the quantity, localization, and efficiency of the final product in the cell (Faurobert et al., 2007). The change of protein abundances reflects the cellular response to the environment, and some changes like post-translational modifications can only be seen at the protein level [4].

The miRNAs play a vital regulatory function in eukaryotic gene expression by binding specific sequences in target genes and suppressing their expression. Plant miRNAs were first identified in early 2002 [5]. As in other aspects, not much information exists related to miRNAs in fruit ripening. The main strategy is to use a omic technology in order to find the control molecules for regulation of fruit development in prickly pear.

\section{Experiments}

\subsection{Plant Materials}

Prickly pears from three Opuntia morphospecies with different development and ripening characteristics were used for this study: 'Naranjona' (early ripening) ‘Blanca Cristalina' (intermediate ripening), and 'Charola' (late ripening). All species were harvest to green $(G)$, middle-ripe (MR), and ripe $(R)$ stages. samples were sliced, ground to a in a mortar with liquid nitrogen and stored at -80 ${ }^{\circ} \mathrm{C}$ until use.

\subsection{Protein Extraction}

Proteins were extracted from $5 \mathrm{~g}$ of prickly pear fruit previously ground, three extractions were carried out for each stage using the phenol method [6]. The concentrations of proteins were quantified with the BCA assay kit from Pierce (Rockford, IL, USA). The concentration of protein was estimated at $562 \mathrm{~nm}$ in a Beckman DU-600 spectrophotometer (Beckman, IL, USA).

\subsection{Two-Dimensional Electrophoresis}

The proteins were first separated according to their charge in $17 \mathrm{~cm}$ long Immobiline dry strips, pH 4-7 (Amersham Bioscience, AB, Uppsala, Sweden). Isoelectric focusing including active rehydration at $20^{\circ} \mathrm{C}$, was performed with the PROTEAN IEF Cell (Biorad, CA, USA) and a Running Preset method. After IEF, the strips were equilibrated for application to the second dimension (SDSPAGE) The second dimensión was done on $12 \%$ SDS-polyacrylamide gels $(16 \times 20 \mathrm{~cm})$. The isolated proteins were quantitatively and qualitatively compared using gels stained with colloidal Coomassie Blue.

\subsection{Image Acquisition and Differential Analysis}

For each treatment, three replicated 2-D gels were made for differential analysis; the gels were scanned and analyzed. Image acquisition was performed using a GS-800 Imaging Densitometer (BioRad, UK) with a resolution of $150 \mathrm{dpi}$; the image analysis was performed using ImageMaster 2D Platinum version 5 software (Amersham Biosciences, Sweden).

In order to compare the protein expression in different conditions, the gels were overlapping (match) to create the master gels. The WM and pI were detected automatically, and the images grouped in agreement to ripening stage, and the gel with the highest number of spots was considered the image master. 


\subsection{MALDI-TOF MS Analysis}

Protein spots whose expression profiles were significantly different between the morphospecies, were excised manually from the gel and digested prior to mass spectrometry assay For matrixassisted laser desorption/ionization time-of-flight mass spectrometry (MALDI-TOF MS) analysis (Voyager, Applied Biosystems, Framingham, MA, USA), For initial protein identification, the spots were selected for mass spectrometry by spot picking from preparative gels. We used MASCOT software (Matrix Science, London, UK) which uses MOWSE (Daresbury, UK) algorithm to search a database for PMFs. The following parameters were used for a standard database search: a minimum of three peptides of the spectrum matched to the protein was required for validation.

\subsection{Microarray for Prickly Pear miRNAs}

In order to analyze the conserved miRNAs in prickly pear, total RNA was hybridized to the GeneChip ${ }^{\circledR}$ miRNA 2.0 Array (Affymetrix). Samples of total RNA include fecunded flowers, green fruits and ripe fruits. The samples at different stages were hybridized in an independent way. RNAs were hybridized at Unidad de Genotipificación y Análisis de Expresión (Instituto Nacional de Medicina Genómica-INMEGEN, Mexico).

RNA of each sample was labeled with biotin and hybridized to separate arrays [7]. Affymetrix fluidic station 450 was used for the wash and stain operation of the arrays. The image was captured with the Scanner Unit model "3000 7G".

The R software, available from the Bioconductor Project (http://www.bioconductor.org), was used to normalize data before comparison and to evaluate differential expression between pool samples. Data normalization was made using the Robust Multichip Average (RMA) method [8]. It consists of three steps: a background adjustment, quantile normalization and finally summarization. All differential expression where selected from at least $>2 \times$ fold change using the oligo [9] and lima [10] packages.

\subsection{RT-Loop PCR.}

The method is based on the stem loop primer [11]. The reaction with a final volume of $4 \mu \mathrm{L}$ contained $2 \mu \mathrm{g}$ of total RNA from the samples, $1 \mu \mathrm{L}$ of $10 \mathrm{mM}$ dNTPs, $2 \mu \mathrm{L}$ of $2.5 \mu \mathrm{M}$ miR RT loop primers, $4 \mu \mathrm{L}$ of Reaction buffer $5 \times, 0.5 \mu \mathrm{L}$ RiboLock RNase (20 U $\mu \mathrm{L}-1), 1 \mu \mathrm{L}$ of RevertAid H Minus RT (200 U $\mu \mathrm{L}-1)$ (ThermoScientific, USA).

A mixture of RNA, primer and dNTPs was incubated to $65^{\circ} \mathrm{C}$ for $5 \mathrm{~min}$ and cooled $5 \mathrm{~min}$ in ice. Then the reaction was completed and incubated to $16^{\circ} \mathrm{C}$ for $30 \mathrm{~min}$, followed by 60 cycles of $20^{\circ} \mathrm{C}$ for $30 \mathrm{~s}, 42{ }^{\circ} \mathrm{C} 30 \mathrm{~s}$ and $50^{\circ} \mathrm{C}$ for $1 \mathrm{~s}$. The transcriptase was inactivated at $85^{\circ} \mathrm{C}$ for $10 \mathrm{~min}$ and cooled at $4{ }^{\circ} \mathrm{C}$.

\section{8. $P C R$}

The reaction contained $1 \mu \mathrm{L}$ of cDNA from the RT loop PCR, $0.2 \mu \mathrm{L}$ of Taq DNA polymerase (5U $\mu \mathrm{L}-1$ ) (ThermoScientific, USA), $2 \mu \mathrm{L}$ of $10 \times$ PCR buffer, $0.8 \mu \mathrm{L}$ of $50 \mathrm{mM} \mathrm{MgCl} 2,1 \mu \mathrm{L}$ of dNTPs, $3.2 \mu \mathrm{L}$ of $2.5 \mu \mathrm{M}$ miR PCR Forward primer, $3.2 \mu \mathrm{L}$ of $2.5 \mu \mathrm{M}$ miR PCR Reverse primer, in a final volume of $20 \mu \mathrm{L}$. The PCR program included $95^{\circ} \mathrm{C}$ for $10 \mathrm{~min}, 55^{\circ} \mathrm{C}$ for $2 \mathrm{~min}, 35$ cycles of $95^{\circ} \mathrm{C}$ for $1 \mathrm{~s}, 65^{\circ} \mathrm{C}$ for $1 \mathrm{~min}$; with a final amplification of $72{ }^{\circ} \mathrm{C}$ for $5 \mathrm{~min}$. The products were analyzed on a $4 \%$ agarose gel, included the Low Range ssRNA Ladder (New England BioLabs) as molecular marker.

\section{Results and Discussion}

\subsection{Proteomic Analysis}

A comparative proteomic analysis from different ripening stages was analyzed by twodimensional electrophoresis (2-DE) according to their $\mathrm{pI}$ and WM. Hundreds of proteins in the range of $\mathrm{pH} 4$ to 7 and WM range of 10 to $220 \mathrm{kDa}$ were resolved. The total number of detected spots varied 
according to the ripening stage and in each morphospecies. An average of about 920 spots from prickly pear was visible on the gels. The progress of fruit ripening was accompanied by a change in the expression of proteins displayed by 2-DE. We observed that there is a great variability in the intensity and size of proteins expressed in different profiles. After triplicate 2-DE analyses of the ripening stages of each morphospecies, qualitative and quantitative differences were observed. The largest number of proteins was concentrated in the range of 30-60 kDa and 5.2-6.0 pI; this distribution was observed in all morphospecies.

Similar to a gene expression profile, proteomics offers the opportunity to examine simultaneous changes and to classify the accumulation of temporal patterns of proteins that occur in complex developmental processes (Cánovas et al., 2004). After separation through 2-DE several hundred individual protein were quantified in all ripening stages. Data from 2-DE analysis were generated with an image analysis software, which detects and quantifies the protein abundances and matches the proteins across the different replicated gels. The matching quality is dependent on the software algorithm, and is determined by the quality and reproducibility of the gels. A high correlation between all comparisons was demonstrated, indicating that the quality of the replicates obtained from the different stages and the different morphospecies of this study was optimal.

Despite the increasing interest in plant proteomics [12], there have been no results for prickly pear fruit proteomics. The contrasting and abundant proteins between the morphospecies were analyzed for protein identification, and the sequences were compared initially in databases. The identified proteins showed identity with proteins previously reported and related to processes associated with ripening in several other fruits. The identified sequences correspond to photosynthesis-related proteins, proteins involved with development and cell wall structure, proteins of fatty acids, flavonoid synthesis, and proteins related to plant resistance and primary metabolism. An important fraction (20\%), were identified as transcription factors and regulatory proteins (Table 1), it suggests a regulatory processes differnt tan transcriptional induction, with important control on regulatoty proteins. It makes reasonable to start looking for other regulatory mechanisms, such as miRNA expression.

Table 1. Identification of some of the regulatory proteins associated to prickly pear fruit development.

\begin{tabular}{llll}
\hline Protein & pI & MW & Function \\
\hline Soybean LEA protein & 6.7 & 25.3 & Protein stability \\
\hline NBS-type putative resistance protein & 6.2 & 25 & Transcription factor \\
\hline Zinc Finger, CCHC-type & 5.9 & 18 & Trascription factor \\
\hline Chalcone flavone isomerase & 6.0 & 21 & Anthocyanin synthesis \\
\hline Omega-6 fatty acid desaturase, chloroplastic & 5.4 & 21 & Fatty acid synthesis \\
\hline
\end{tabular}

\section{2. miRNA Analysis}

615 miRNA sequences were analyzed, and several families were found, i.e., miR-159 (target for $M Y B$ genes, that bind to the Leafy promoter in flower identity), miR-164 (target for NAC domain proteins; that cooperate with CUC2 in the floral growth), or miR-168 (target of Argonaute1), that regulates meristem formation and participates in leaf development).

The miRNA expression was tested with RT-PCR loop, as described. A differential expression was observed at the different stages of development (floral buds, flowers and fertilized flowers, green and ripe fruits). The expression at the fecunded flowers stage in most of the analyzed miRNAs, such as miR159 (target of GAMYB-like gene that participates in flowering and gibberellin signaling). Mainly of the miRNA induced expression are associated to the control of important developmental processes, they regulate the activity of several transcription factors. Some families of miRNAs were identified and the possible route for the stablisment for embryo and seed formation was determined (Table 2). 
Table 2. miRNAs associated toprickly pear fruit development.

\begin{tabular}{lcc}
\hline miRNA & Target & Function \\
\hline miR156 & SPL10, SPL11, SPL13A, SPL13B, SPL2, SPL9 & $\begin{array}{c}\text { Floral induction, } \\
\text { carotenoids and bethalains } \\
\text { production, anthocianins synthesis }\end{array}$ \\
\hline miR160 & ARF17, ARF10, ARF16 & $\begin{array}{c}\text { Floral induction } \\
\text { Flower development }\end{array}$ \\
\hline miR398 & $\begin{array}{l}\text { Core-2/I-branching Beta-1,6-N- } \\
\text { acetylglucosaminyltransferase }\end{array}$ & Floral induction \\
\hline miR397 & LAC17, LAC2, LAC4 & Seed production \\
\hline miR172 & TOE2, AP2, FLO2, FL1 & $\begin{array}{c}\text { Floral definition } \\
\text { Ripening delay }\end{array}$ \\
\hline miR171 & MIR171C & SAM regulator \\
\hline miR395 & ATPS1, ATPS3, ATPS4, SULTR2;1 & Sulfur metabolism \\
\hline miR387 & SPL10, SPL11, SPL15, SPL2, SPL9 & Anthocianins synthesis \\
\hline miR529 & & Embryo maduration \\
\hline
\end{tabular}

\section{Conclusions}

The optimal conditions for the first comparative proteomic analysis were stablished during the ripening of non-climacteric fruits with contrasting characteristics of ripening, using prickly pear fruit as a model. 2-DE profiles showed changes in the proteome of prickly pear fruits with contrasting ripening and at different stages of ripening; these changes revealing the high synthesis and differential expression of proteins during ripening of prickly pear fruits. Proteins associated with fruit ripening, and with specific activities were identified.

Microarray profiles showed changes in the miRNA transcriptome of prickly pear fruits with contrasting ripening and at different stages of fruit development. These changes revealed the high synthesis and differential gene expression control during development of prickly pear fruits. microRNAs with specific activities, associated with fruit ripening and development.

Author Contributions: A.C.-H., M.A.-V. and A.C.-R. conceived the Project and designed the experiments. A.C.H. performed the experiments, A.-C.H., M.A.-V. and A.C.-R. analyzed the data. A.C.-H. wrote the manuscript with inputs from all co-authors. All authors have read and agreed to the published version of the manuscript.

Acknowledgments: Thanks to CONACyT and Universidad De La Salle Bajio for financial support.

Funding: This work was funded by CONACyT-Mexico, Universidad De La Salle Bajio.

Conflicts of Interest: The authors declare no conflict of interest.

\section{References}

1. Pimienta-Barrios, E. Prickly pear (Opuntia spp.): A valuable fruit crop for the semiarid lands of Mexico. J. Arid Environ. 1994, 28, 1-11.

2. Prasanna, V.; Prabha, T.N.; Haranthan, R.N.T. Fruit ripening phenomena-An overview. Crit. Rev. Food Sci. Nutr. 2007, 47, 1-19.

3. Giovannoni, J.J. Molecular regulation of fruit ripening. Annu. Rev. Plant Physiol. Plant Mol. Biol. 2001, 52, 725-749.

4. Alm, R.; Ekefjard, A.; Krogh, M.; Hakkinen, J.; Emanuesson, C. Proteomic variation is as large within as between strawberry varieties. J. Proteome Res. 2007, 6, 3011-3020.

5. Llave, C.; Kasschau, K.D.; Rector, M.A.; Carrington, J.C. Endogenous and silencing-associated small RNAs in plants. Plant Cell 2002, 14, 1605-1619, doi:10.1105/tpc.003210.

6. Saravanan, R.S.; Rose, J.K.C. A critical evaluation of sample extraction techniques for enhanced proteomic analysis of recalcitrant plant tissues. Proteomics 2004, 4, 2522-2532. 
7. Lockhart, D.J.; Dong, H.; Byrne, M.C.; Follettie, M.T.; Gallo, M.V.; Chee, M.S.; Mittmann, M.; Wang, C.; Kobayashi, M.; Norton, H.; et al. Expression monitoring by hybridization to high-density oligonucleotide arrays. Nat. Biotechnol. 1996, 14, 1675-1680, doi:10.1038/nbt1296-1675.

8. Irizarry, R.A.; Bolstad, B.M.; Collin, F.; Cope, L.M.; Hobbs, B.; Speed, T.P. Summaries of Affymetrix GeneChip probe level data. Nucleic Acids Res. 2003, 31, e15, doi:10.1093/nar/gng015.

9. Carvalho, B.S.; Irizarry, R.A. A framework for oligonucleotide microarray preprocessing. Bioinformatics 2010, 26, 2363-2367, doi:10.1093/bioinformatics/btq431.

10. Smyth, G.K.; Michaud, J.; Scott, H.S. Use of within-array replicate spots for assessing differential expression in microarray experiments. Bioinformatics 2005, 21, 2067-2075, doi:10.1093/bioinformatics/bti270.

11. Li, H.; Zhang, Z.; Huang, F.; Chang, L.; Ma, Y. MicroRNA expression profiles in conventional and micropropagated strawberry (Fragaria $\times$ ananassa Duch.) plants. Plant Cell Rep. 2009, 28, 891-902, doi:10.1007/s00299-009-0693-3.

12. Cánovas, F.M.; Dumas-Gaudot, E.; Recorbet, G.; Jorrin, J.; Mock, H.P.; Rossignol, M. Plant proteome analysis. Proteomics 2004, 4, 285-298.

Publisher's Note: MDPI stays neutral with regard to jurisdictional claims in published maps and institutional affiliations.

(C) 2020 by the authors. Licensee MDPI, Basel, Switzerland. This article is an open access article distributed under the terms and conditions of the Creative Commons Attribution (CC BY) license (http://creativecommons.org/licenses/by/4.0/). 